\title{
Visioscan-Driven ULEV Method
}

\author{
Gérald E. Piérard, Claudine Piérard-Franchimont, \\ and Sébastien Piérard
}

\subsection{Introduction}

Melanocytes and their melanins govern the phototype-related color of the skin. Indeed, the color palette of the skin largely depends on the molecular nature and amount of melanins (eumelanin and pheomelanin) and on the size, shape, and distribution of melanosomes produced by melanocytes and transferred into keratinocytes. Such combinations define what could be called the individual melanotype.

The epidermal melanin unit refers to a microscopic functional entity composed of one single melanocyte and its adjacent keratinocytes into which the melanosomes are transferred. Chronic ultraviolet (UV) light exposures represent positive stimulatory signals to the epidermal melanin units. In such instance, both the active melanocytes are increased in number, and each individual melanocyte is stressed to produce more melanins. In addition, melanosome transfer from melanocytes to adjacent keratinocytes is boosted through the intervention of the protease-activated receptor 2 [1].

\footnotetext{
G.E. Piérard, MD, PhD ( $₫)$

C. Piérard-Franchimont

Laboratory of Skin Bioengineering

and Imaging, Department of Dermatopathology,

University Hospital of Liège, CHU Sart Tilman,

Liège B-4000, Belgium

e-mail: gerald.pierard@ulg.ac.be

S. Piérard

Telecommunications and Imaging Laboratory,

INTELSIG, Montefiore Institute,

University of Liège, Liège, Belgium
}

According to the native individual melanotype, age, and cumulative UV exposures, the skin commonly develops a discrete to severe mottled appearance. Freckles in youths and solar lentigines in older individuals are typical clinical expressions of such events. The clinical aspects are due to an increase in the keratinocyte melanin content (melanotic hypermelanosis) associated or not with melanocytic hyperplasia. The resulting mottled pigmentation is an early key feature of photoaging.

\subsection{Clinical Recordings}

Photography under UVA light, which is largely absorbed by melanin, was a convenient way to highlight any discrete regional change in skin pigmentation [2-7]. Provided that the lightning was kept constant and the camera calibrated beforehand, this technique revealed with confidence pigmentation changes. Using a UVA source of lighting (Wood's light), any skin blemish was thus conveniently assessed by a regular photography system [2-7]. As such, UV photography was used as a diagnostic tool, but it was rarely employed for measuring the intensity of pigmentation. Indeed, the latter application was not satisfactory because casual equipments generated shadows focally superposed to the skin pigmentation. In order to thwart to this drawback, a CCD camera equipped with an internal UV-emitting unit (Visioscan ${ }^{\circledR}$ VC98, C + K electronic, Cologne, Germany) was designed. 
The Visioscan ${ }^{\circledR}$ VC98 sensor chip is closely applied to the skin surface in order to avoid shadows. The uniform illumination of the skin brings out a sharp video picture of a $6 \times 8 \mathrm{~mm}$ area of the skin surface. The high resolution of the video capture allows close assessments of the skin. The computer connection of the Visioscan ${ }^{\circledR}$ VC98 is made through an image digitalization unit configuring a 256 gray level picture, where 0 corresponds to black and 256 to white. The camera-based image analysis leads to the so-called UV lightenhanced visualization (ULEV) method $[8,9]$.

The ULEV picture results from the combined reflectance and absorption of the incident UV light by the skin structures [10]. Specular reflectance is mainly modulated by the stratum corneum (SC) roughness. The SC surface of scaly dermatoses appears whitish. Once the UV light has crossed the epidermis, the residual UV wavelengths reach the fibrous structures of the dermal extracellular matrix which in turn emit fluorescence. Following its way back to the skin surface, the reflected and/or emitted light is captured by the recording CCD camera. During both the way in and way out through the skin, the UV light is possibly absorbed by two main chromophores, namely, melanins and hemoglobin. Melanin absorption exerts a prominent effect by reducing the light received by the CCD camera. Hemoglobin exerts a similar effect when present in abundance inside superficial hemangiomas. By contrast, the regular amount of blood in superficial blood vessels has no significant effect because fluorescent connective tissue fibers are interposed between the vessels and the skin surface.

The Visioface ${ }^{\circledR}$ Quick $(\mathrm{C}+\mathrm{K}$ electronic) is another tool providing pictures similar to ULEV. The light booth contains 200 white diodes (LED) uniformly illuminating the exposed skin area. The camera (Canon Powershot A640 with a 10.2 megapixel resolution) and light sources are computer-controlled. After applying adequate software filtering of the cyan hue, the image increases the contrast created by melanin [11].

The Visioscan ${ }^{\circledR}$ VC98 contains a camerabased image analysis system allowing the evaluation of the skin surface. The surface evaluation of living skin (SELS) software generates two relevant parameters in the evaluation of skin surface changes. The smoothness parameter (SESM) is proportional to the depth and width of furrows, and the wrinkling parameter (SEW) is proportional to the number and width of furrows.

\subsection{Subclinical Melanoderma}

The mottled subclinical melanoderma (MSM) is a mosaic pattern of skin pigmentation typically revealed under ULEV examination [8, 9]. This feature is particularly prominent in photosensitive individuals with a light melanotype and pheomelanin-enriched phenotype [8]. Using the Visioscan-driven ULEV method, the increased contrast between the faint almost invisible spotty melanosis and the surrounding skin is the combined result of a greater fluorescence emission than visible light by collagen and the greater UVA and fluorescence absorption by melanin inside the epidermis. The boundary between MSM macules and the skin in close vicinity is sharply delimited.

Since UV light penetrates less deeply into the skin than visible light, it is considered that both the regular UV photography and the ULEV method mainly catch the intraepidermal pigmentation. Thus, melanin located in the dermis is not detected using these methods. Therefore, a clear distinction is made using ULEV between enhanced melanotic hypermelanosis and any dermal melanoderma. Such distinction is useful because the former type is accessible to depigmenting treatments, while the latter type is unresponsive and persists as a melanin tattoo. These two conditions coexist for instance in facial melasma.

Several MSM patterns were identified [8-13]. They are listed in Table 2.1. Spotty perifollicular dots are commonly seen on the scalp and face (Fig. 2.1), occasionally extending to other seborrheic regions [8, 11-14]. This physiologic perifollicular pattern is recognized as early as during adolescence, and it does not seem altered by aging. By contrast, the interfollicular area exhibits a combination of pinpoint lesions, small macules, and globular macules [8]. Such a pattern appears during adult life and is subject to variations with cumulative photoexposures and aging. 
Table 2.1 Patterns of subclinical skin mottling

Pinpoint: minute irregularly distributed darker spots Follicular dots: speckled perifollicular darker rings Small macules: small interfollicular darker areas Globular macules: accretive and circinate confluence of smaller macules

Streaky macules: elongated darker areas along wrinkles Confluent macules: massive darker areas

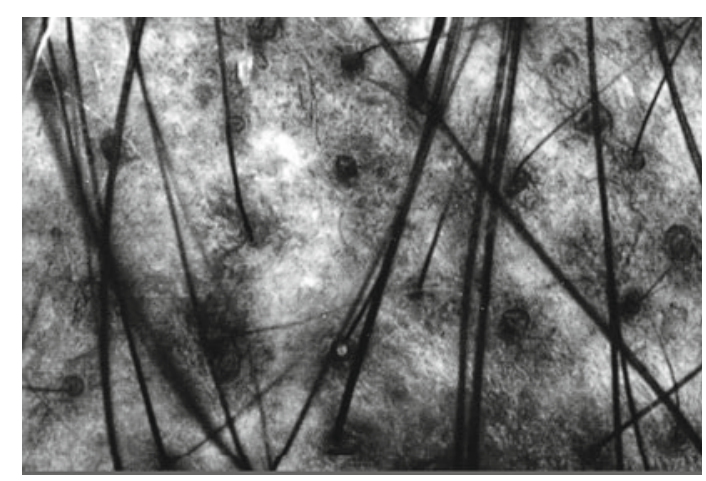

Fig. 2.1 Spotty perifollicular MSM on the scalp

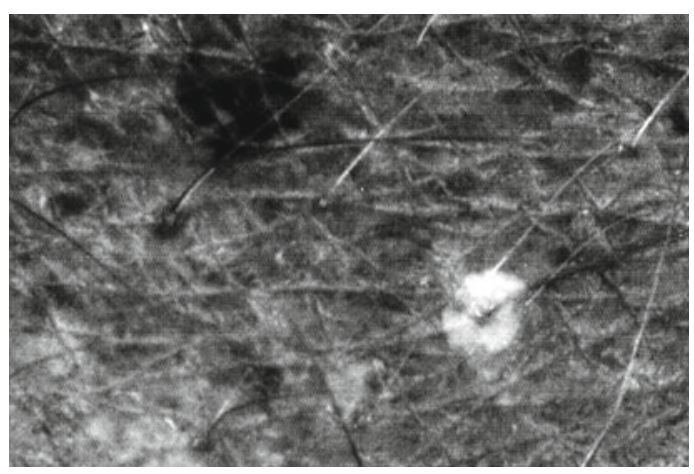

Fig. 2.2 Hypopigmented spot in an area showing darker MSM spots

These discrete hypermelanotic blemishes progressively coalesce, and they appear more prominent on chronically sun-exposed skin. This aspect is regarded as an early sign of photoaging $[9,11$, $15,16]$. Still another MSM aspect corresponds to the streaky pattern elongated along wrinkles [8]. This aspect is typically present on the sunny-side slope of facial frown lines [8].

Hypochromic spots associated with MSM (Fig. 2.2) are possibly present in genetic disorders of pigmentation [17] and in ethnic darker skin [18]. They also develop on chronically UV-exposed skin such as in worshipers of recreational sunbeds [19].

\subsection{Assessment of Whitening Agents}

The ULEV method is employed for assessing the efficacy of cosmetic whitening products [8, 20-24]. Computerized image analysis of the pictures offers objective quantification of the depigmenting effect on the epidermal melanin units. The method was applied for assessing "brown spots" corresponding to solar lentigines or incipient pigmented seborrheic keratoses [20-22]. Such evaluations are more easily handled than the bleaching effect on melasma [22]. Using the ULEV method, the observed effects of whitening agents cannot be distinguished according to the putative biologic effects on tyrosinase, protease-activated receptor-2, or any other step of melanization.

Beyond conventional cosmetic whitening agents, some drugs alter the activity of the epidermal melanin units. Both topical corticosteroids and vitamin D analogues decrease the MSM severity as assessed by the ULEV method [16].

\subsection{Skin Surface Microrelief and Scaliness}

Any ULEV quantitative assessment of the skin surface microrelief is of interest in evaluating some therapeutic and cosmetic interventions, as well as for the determination of the severity in irritation damages to the skin. Indeed, any measurement where skin is optically monitored using an image digitalization process without any sampling or replica collection represents a technological advance [25-27]. The regular observation of ULEV pictures reveals any hyperkeratotic and scaly aspects of the skin surface (Fig. 2.3). The lesions look whitish contrasting with the gray aspect of the normal-looking skin [25-27].

UVA emitted by the Visioscan ${ }^{\circledR}$ VC98 clearly highlights desquamation in vivo. A semiquantitative assessment is possible, but the data interpretation is 


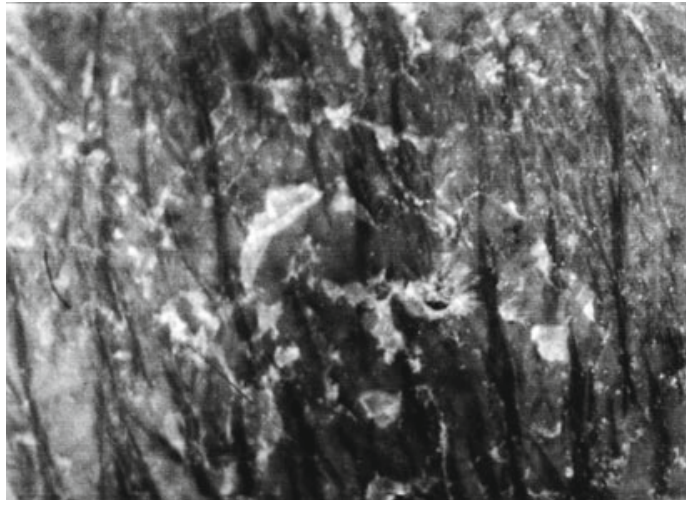

Fig. 2.3 Scaly stratum corneum showing bright white reflectance

not always straightforward. For improving this assessment using the Visioscan ${ }^{\circledR}$ VC98, sampling the SC can be performed using transparent sticky Corneofix $^{\circledR}$ F20 tapes $(\mathrm{C}+\mathrm{K}$ electronic). After slightly pressing the sampling tape onto the skin surface, the superficial corneocytes adhere to the tape and are harvested for the assessment of their numbers and sizes. As the light is absorbed differently due to the different thickness of corneocyte clumps, they appear as darker pixels in the image. A quantitative assessment is performed looking at the gray level distribution in the histogram. The regular Visioscan ${ }^{\circledR}$ software distinguishes five scaliness levels. The drawback of this automatic cutting is that the shutter does not properly recognize the background in some images. In these instances, the observer can set the shutter manually by comparing the original and the segmented images with a $0.1 \%$ accuracy. Under ULEV examination, dandruff appears as small white objects dispersed along hair shafts [28-30]. Due to the high contrast with hair, a quantitative assessment is made possible without any specific sampling procedure.

The SELS method represents another quantitative assessment of the skin roughness [31].

\subsection{Comedogenesis}

At the hair follicle openings at the skin surface, microcomedones and keratin-filled funnel-like acroinfundibula are easily identified using ULEV examination. The method proved to be useful in the assessment of comedogenic and comedolytic compounds. In addition, acne physiopathology is highlighted by this method [32].

Cancer patients under targeted chemotherapy to the epidermal growth factor receptor (EGFR) frequently suffer from unusual skin adverse events. The Visioscan ${ }^{\circledR}$ camera revealed specular light reflectance at the site of follicular plugging [33]. The interfollicular stratum corneum showed occasional focal hyperkeratosis. These features increased in severity with the duration of the EGFR inhibitor treatment, indicating follicular involvement as an early adverse event of the therapy. EGFR inhibitorinduced kerosis (follicular hyperkeratosis) is likely responsible for acneiform reactions.

\subsection{Sebum Excretion}

Sebum flow dynamics can be assessed using lipid-sensitive films [34]. The assessment benefits from image analysis of the sebum-enriched spots. The Visioscan ${ }^{\circledR}$ VC98 camera is conveniently used for that purpose [32]. The camera is covered by the opaque microporous lipidsensitive Sebufix ${ }^{\circledR}$ F16 foil $(\mathrm{C}+\mathrm{K}$ electronic) before application onto the skin. After about $30 \mathrm{~s}$, the mean instant sebum follicular output (SFO) corresponding onto the area of the transparent spots of lipid droplets is assessed using computerized image analysis. The face of the Sebufix ${ }^{\circledR} \mathrm{F}$ 16 in contact with the skin is glue-free. Thus, sebum fills in the micropores of the sebumsensitive foil without any restriction (Fig. 2.4). This leads to a short measuring time after which the foil is ready to be evaluated. This requirement is important in order to avoid any artifactual occlusion effect. Indeed, occlusion leads to the stratum corneum swelling and to the increased skin temperature influencing the sebum flow.

The more oily the skin, the shorter collecting time is necessary. Assessments performed any time after cleansing the skin is thus possible. The lipid-sensitive film is lightly present but constantly on the skin leading to reproducible measurements. The special foil typically measures the sebum output from the follicular reservoir. 


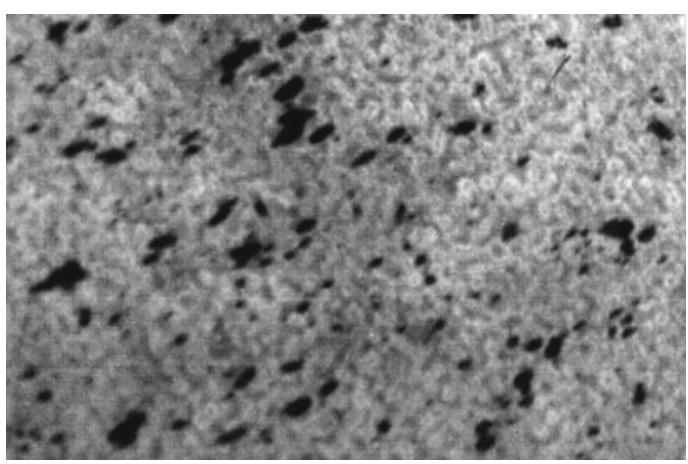

Fig. 2.4 Sebum dots on a lipid-sensitive foil

With this procedure, the sebum output at the skin surface can be monitored live in real time.

\subsection{Hair Graying}

The loss of melanin content in the hair shaft is a natural manifestation of aging leading to hair graying. Such phenomenon can be observed as early as 20 years of age in Caucasians and about 30 years in Africans; it has been reported that on average, in a cohort of Caucasians, $50 \%$ of people had at least $50 \%$ gray hair when reaching 50 years old [35]. The biologic processes underlying hair graying remain unclear [36]. In addition, the process of hair graying is difficult to assess and quantify in vivo. The ULEV method highlights this physiologic phenomenon by enhancing the contrast between graying hair appearing bright white and the other hair shafts.

\subsection{Trichobacteriosis}

Some bacterial species tend to clump along hair shafts, particularly in the axillae. They are embedded in a biofilm. This condition corresponds to trichobacteriosis formerly called trichomycosis. The ULEV method is a convenient way to observe these structures appearing as bright white sheaths encasing the base of the hair shafts. This aspect is probably related to the fluorescence emitted by trichobacteriosis under Wood's light. A similar phenomenon can occur at the site of other fluorescent lesions such as erythrasma and pityriasis (tinea) versicolor.

\subsection{Risk Assessment of Skin Cancers}

A correlation was found between MSM severity and the risk for developing actinic keratoses and basal cell carcinomas on facial skin and the scalp [37-42]. A peculiar aspect corresponds to focal depigmentation suggesting the destruction of some epidermal melanin units. Such finding could help identifying in early adult life subjects at risk of skin cancers.

\subsection{Xenobiotic Deposits onto the Skin}

Some exogenous compounds adhering to the stratum corneum are conveniently observed using the Visioscan ${ }^{\circledR}$ VC98. For instance, the antiperspirant aluminum hydroxychloride shows peculiar patterns of deposits at the skin surface [43].

\section{Conclusion}

UVA photography and its more recent development using a CCD camera equipped with an internal UVA-emitting unit are useful by different aspects. The MSM revealed by the ULEV method is possibly the earliest clinical manifestation of photoaging. In addition, the same method highlights scaliness and desquamation as well as a series of other specific conditions at the skin surface.

Acknowledgments This work was supported by a grant from the "Fonds d'Investissement de la Recherche Scientifique" of the University Hospital of Liège. No other sources of funding were used to assist in the preparation of this manuscript. The authors have no conflicts of interest that are directly relevant to the content of this review. The authors appreciate the excellent secretarial assistance of Mrs. Ida Leclercq and Marie Pugliese.

\section{References}

1. Seiberg M, Paine C, Sharlow E et al (2000) The proteaseactivated receptor 2 regulates pigmentation via keratinocytes-melanocyte interactions. Exp Cell Res 254:25-32

2. Gilchrest BA, Fitzpatrick TB, Anderson RR, Parrish JA (1977) Localization of melanin pigmentation in the skin with Wood's lamp. Br J Dermatol 96:245-248 
3. Kikuchi I, Idermori M, Uchimura H, Inoue S (1983) Reflection ultraviolet photography as surface photography of the skin. J Dermatol 10:551-555

4. Masuda Y, Takei K, Mizugaki M (1996) Quantification of the face brown spots and freckles with image analysis method. J Soc Cosmet Chem Jpn 28:147

5. Arai S (1997) Analysis of pigmentation of human skin (UV-light images). In: Wilhem KP, Elsner P, Berardesca Maibach HI (eds) Bioengineering of the skin. Skin surface imaging and analysis. CRC Press, Boca Raton, pp 85-94

6. Fulton JE (1997) Utilizing the ultraviolet (UV detect) camera to enhance the appearance of photodamage and other skin conditions. Dermatol Surg 23:163-169

7. Kollias N, Gillies R, Cohen-Goihman C, Phillips SB, Muccini JA, Stiller M, Drake LA (1997) Fluorescence photography in the evaluation of hyperpigmentation in photodamaged skin. J Am Acad Dermatol 36:226-230

8. Hermanns JF, Petit L, Piérard-Franchimont C et al (2000) Unravelling the patterns of subclinical phaeomelaninenriched facial hyperpigmentation. Effect of depigmenting agents. Dermatology 201:118-122

9. Petit L, Fougouang L, Uhoda I et al (2003) Regional variability in mottled photo-induced melanoderma in the elderly. Exp Gerontol 38:327-331

10. Szepetiuk G, Piérard S, Piérard-Franchimont C, Caucanas M, Quatresooz P, Piérard GE (2011) Recent trends in specular light reflectance beyond clinical fluorescence diagnosis. Eur J Dermatol 21:157-161

11. Piérard GE, Piérard-Franchimont C, Quatresooz P (2012) Field melanin mapping of the hairless scalp. Skin Res Technol 18(4):431-435

12. Petit L, Piérard-Franchimont C, Saint Léger D et al (2002) Subclinical speckled perifollicular melanosis of the scalp. Eur J Dermatol 12:565-568

13. Xhauflaire-Uhoda E, Hermanns JF, Piérard-Franchimont C et al (2006) Highlighting the rim of perifollicular epidermal unit. Eur J Dermatol 16:225-229

14. Uhoda E, Piérard-Franchimont C, Petit L et al (2005) The conundrum of skin pores in dermoscosmetology. Dermatology 210:3-7

15. Barel AO, Alewaeters K, Clarys P (1999) Optical imaging using UV light for the determination of photoageing. Skin Res Technol 5:126

16. Piérard-Franchimont C, Paquet P, Quatresooz P et al (2007) Smoothing the mosaic subclinical melanoderma by calcipotriol. J Eur Acad Dermatol Venereol 21:657-661

17. Devillers C, Quatresooz P, Hermanns-Lê T et al (2011) Hypomelanosis of Ito: pigmentary mosaicism with immature melanosomes in keratinocytes. Int J Dermatol 50:1234-1239

18. Hermanns JF, Hermanns-Lê T, Piérard GE (2007) Faint innate hypomelanotic spotting in black skin. Eur J Dermatol 17:353-354

19. Piérard-Franchimont C, Piérard GE, Quatresooz P (2012) The skin ivory spot. Predictive sign for skinfield carcinogenesis. Int J Environ Res Public Health 9:362-369

20. Hermanns JF, Petit L, Piérard-Franchimont $\mathrm{C}$ et al (2002) Assessment of topical hypopigmenting agents on solar lentigines of Asian women. Dermatology 204:281-286

21. Petit L, Piérard GE (2003) Analytic quantification of solar lentigines lightening by a $2 \%$ hydroquinonecyclodextrin formulation. J Eur Acad Dermatol Venereol 17:546-549

22. Thirion L, Piérard-Franchimont C, Piérard GE (2006) Whitening effect of a dermocosmetic formulation. A randomized double-blind controlled study on melasma. Int J Cosmet Sci 28:263-267

23. Piérard-Franchimont C, Henry F, Quatresooz P, Vroome V, Piérard GE (2008) Analytic quantification of the bleaching effect of a 4-hydroxyanisole-tretinoin combination on actinic lentigines. J Drugs Dermatol 7:873-878

24. Piérard GE, Seite S, Rougier A, Quatresooz P (2011) Analytic assessment under ultraviolet light of actinic lentigines under bleaching treatment. J Cosmet Dermatol 10:102-107

25. Pena Ferreira R, Costa P, Bahia F (2003) Visioscan VC 98 application : a comparison study between coarse and smooth surface. Skin Res Technol 9:204-205

26. Uhoda E, Piérard-Franchimont C, Petit L et al (2003) Skin weathering and ashiness in black Africans. Eur J Dermatol 13:574-578

27. Uhoda E, Petit L, Piérard-Franchimont C et al (2004) Ultraviolet light-enhanced visualization of cutaneous signs of carotene and vitamin A dietary deficiency. Acta Clin Belg 59:97-101

28. Piérard-Franchimont C, Uhoda E, Piérard GE (2005) Quantification of dandruff adherence to hair. Int J Cosmet Sci 27:279-282

29. Piérard-Franchimont C, Xhauflaire-Uhoda E, Piérard GE (2006) Revisiting dandruff. Int J Cosmet Sci 28:311-318

30. Piérard-Franchimont C, Quatresooz P, Piérard GE (2011) Specular light reflectance of flakes in seborrheic dermatitis of the scalp. A pilot study. Clin Exp Dermatol 36:793-796

31. Tronnier H, Wiebuch M, Heinrich U et al (1999) Surface evaluation of living skin. Adv Exp Med Biol 455:507-516

32. Piérard-Franchimont C, Piérard GE (2002) Postmenopausal aging of the sebaceous follicle: a comparison between women receiving hormone replacement therapy or not. Dermatology 204:17-22

33. Piérard GE, Piérard-Franchimont C, Humbert P (2012) Bioimpact of anti-EGFR treatments on the pilosebaceous follicles. Eur J Dermatol 22:54-57

34. Piérard-Franchimont C, Martalo O, Richard A et al (1999) Sebum rheology evaluated by two methods in vivo. Split-face study of the effect of a cosmetic formulation. Eur J Dermatol 9:455-457

35. Keogh EV, Walsh RJ (1965) Rate of graying of human hair. Nature 207:877-878

36. Tobin DJ, Paus R (2001) Graying: gerontology of the hair follicle pigmentary unit. Exp Dermatol 36: 29-54

37. Piérard-FranchimontC, Piérard GE(1998) Heterochromic sun-damaged skin and the risk for skin cancer. Rev Med Liege 53:355-356 
38. Hermanns JF, Henry F, Piérard-Franchimont $\mathrm{C}$ et al (2001) Analytic quantification of aging of the melanocytic system. Implication in the objective détermination of skin cancer risk. Ann Gerontol 15:233-239

39. Quatresooz P, Petit L, Uhoda I et al (2004) Mosaic subclinical melanoderma : an Achilles heel for UV-related epidermal carcinogenesis. Int J Oncol 25: 1763-1767

40. Quatresooz P, Piérard-Franchimont C, Henry F et al (2006) Subclinical melanoderma and photoinduced cancers. In: Uhoda E, Paye M, Piérard GE (eds) Actualités en ingénierie cutanée, vol 4. Publ. Eska, Paris, pp 67-73
41. Xhauflaire-Uhoda E, Piérard-Franchimont C, Piérard GE, Quatresooz P (2010) Weathering of the hairless scalp: a study using skin capacitance imaging and ultraviolet light-enhanced visualization. Clin Exp Dermatol 35:83-85

42. Quatresooz P, Xhauflaire-Uhoda E, PiérardFranchimont C, Piérard GE (2009) Epidermal field carcinogenesis in bald-headed. An attempt at finetuning early noninvasive detection. Oncol Rep 21: 1313-1316

43. Mayeux G, Xhauflaire-Uhoda E, Piérard GE (2012) Patterns of aluminum hydroxychloride deposition onto the skin. Skin Res Technol 18:64-68 